Buana Sains Vol 18 No 1: 29 - 34, 2018

\title{
PENGARUH PYRACLOSTROBIN PADA PEMBENTUKAN BUAH KOPI ROBUSTA (Coffea canephora)
}

\author{
Wiharyanti Nur Lailiya ${ }^{1}$, Karuniawan Puji Wicaksono ${ }^{2}$, dan Eko Widaryanto ${ }^{2}$ \\ ${ }^{1}$ Program Pascasarjana, Fakultas Pertanian, Universitas Brawijaya, Malang \\ ${ }^{2}$ Jurusan Budidaya Pertanian, Fakultas Pertanian, Universitas Brawijaya
}

\begin{abstract}
Robusta coffee (Coffea canephora) is one of the commodities that have high economic value among other plantation crops. Coffee is also one of the three nonalcoholic beverages (coffee, tea, chocolate) are widespread. Indonesia and among the countries located in the international coffee world, because Indonesia is the third largest coffee exporter after Brazil and Vietnam. Coffee production in Indonesia reached an average of 11.250 tonnes per year. The purpose of this study is studying the ability of pyraclostrobin on coffee fertilization, thereby reducing the occurrence of fruit drop and determining the appropriate concentrations for spraying treatment pyraclostrobin on fertilization and reduce fruit drop robusta coffee. This study was conducted in JanuarySeptember 2016 in the coffee plantation Tlogosari, Tirtoyudo subdistrict, Malang regency which is located an altitude of $560 \mathrm{~m}$ above sea level. The method that used in this study is a randomized block design, consisting of 6 treatments and 4 replications. While the treatment is P0 (without spraying), P1 (Spraying once a week with a concentration of $150 \mathrm{ppm}$ ), P2 (Spraying once a week with a concentration of 300 ppm), P3 (Spraying once a week with a concentration of $450 \mathrm{ppm}$ ), P4 (Spraying once a week with a concentration of $600 \mathrm{ppm}$ ), P5 (Spraying once a week with a concentration of $750 \mathrm{ppm}$ ). Giving pyraclostrobin with a concentration of $600 \mathrm{ppm}$ may increase the amount of fruit compared to the treatment without giving pyraclostrobin.
\end{abstract}

Keywords: Robusta coffee; pyraclostrobin; spraying; fruit drop.

\section{Pendahuluan}

Kopi merupakan salah satu komoditas perkebunan yang memiliki peminat cukup besar di tingkat nasional maupun internasional. Dari empat jenis kopi (Arabika, Robusta, Liberika dan Exselsa) kopi Arabika memiliki permintaan hingga 70 persen di pasar dunia tetapi Indonesia hanya menyumbang 10 persen. Jenis Robusta mutunya dibawah Arabika yang memiliki permintaan 24 persen produksi dunia dan Indonesia menyumbang 90 persen dari jumlah tersebut, sedangkan Liberika dan Ekselsa masing-masing 3 persen. Produktivitas kopi Nasional terus menurun mulai tahun 2010-2012. Tetapi, pada tahun 2013 mengalami peningkatan yaitu mencapai $755 \mathrm{Kg} \mathrm{ha}^{-1}$. Sedangkan luas area perkebunan terus meningkat sejak tahun 2010-2013.

Proses pembungaan dan pembuahan tanaman kopi merupakan perubahan fase vegetatif menjadi fase reproduktif. Peristiwa pada terjadinya kerontokan buah biasanya diakibatkan oleh beberapa faktor, diantaranya yaitu kegagalan proses pembuahan, fisiologis dan hama penyakit. Faktor fisiologis 
W.N. Lailiya, K.P. Wicaksono dan E. Widaryanto/ Buana Sains Vol 18 No 1 : 29-34

terjadi melalui pengaruh iklim terutama kelembaban dan kekeringan yang berpengaruh pada kerontokan buah. Selama perkembangan buah diduga terjadi pemindahan karbohidrat dari bagian lain tanaman ke percabangan yang mempunyai pembuahan yang lebat. Apabila kekurangan karbohidrat maka akan terjadi keguguran daun dan buah. Kelembaban yang terlalu tinggi juga menyebabkan terjadi terbentuknya lapisan absisik sehingga sel-selnya menjadi rusak menyerupai tepung dan mendorong terjadinya daun dan buah kopi rontok (Vaast et al., 2005). Pyraclostrobin ialah suatu senyawa dari golongan strobirulin yang dapat menghambat respirasi mitokondria dengan memblokir transfer elektron dalam rantai respirasi (Ammermann et al., 2000). Pyraclostrobin atau dengan nama kimia (methyl N- [2-[1-(4-chlorophenyl)1H-pyrazol-3yl]oxy]methyl]phenyl] methoxy-, methyl ester) diketahui dapat menghambat senescenes dengan cara memperlambat aktivitas sintesa asam 1aminocyclopropane-1 carboxylic (AAC) pada jaringan tunas tanaman (Grossmann dan Retzlaff, 1997). Pyraclostrobin memiliki rumus senyawa $\mathrm{C}_{19} \mathrm{H}_{18} \mathrm{CIN}_{3} \mathrm{O}_{4}$. Unsur $\mathrm{Cl}$ berfungsi sebagain toksin dan unsur $\mathrm{N}$ sebagai penambah unsur hara di dalam tanaman. Nitrogen ialah komponen penting dari asam amino, asam nukleat dan protein.

\section{Metode Penelitian}

Penelitian ini dilakukan di kebun kopi kecamatan Tirtoyudo, kabupaten Malang yang terletak pada ketinggian $560 \mathrm{~m}$ dpl. Penelitian ini dilaksanakan pada bulan Januari-April 2016. Alat yang digunakan berupa kamera dan peralatan tulis lainnya. Untuk kamera digunakan sebagai dokumentasi yang dapat menunjang dan melengkapi data di lapangan. Bahanbahan yang digunakan ialah tanaman kopi arabika yang berumur 4 tahun dan pyraclostrobin. Penelitian ini dilakukan menggunakan metode Rancangan Acak Kelompok yang tediri dari 6 perlakuan dan 4 ulangan. Pengamatan yang dilakukan pada parameter pertumbuhan tanaman meliputi jumlah cluster, jumlah daun, luas daun dan jumlah buah. Sedangkan parameter pengamatan panen meliputi jumlah buah, bobot buah dan hasil buah $\mathrm{t} \mathrm{ha}^{-1}$. Pengamatan destruktif dilakukan untuk mengamati tumlah stomata dan kandungan klorofil. Data pengamatan yang diperoleh dianalisis dengan menggunakan analisis ragam (uji F) pada taraf 5\%.Bila dari hasil pengujiandiperoleh perbedaan yang nyata maka dilanjutkan dengan uji perbandingan antar perlakuan dengan menggunakan Beda Nyata Terkecil (BNT) pada taraf 5\%.

\section{Hasil dan Pembahasan}

Aplikasi pyraclostrobin dapat meningkatkan pertumbuhan tanaman serta meningkatkan hasil pada tanaman kopi. Giuliani et al., (2011) menerangkan bahwa aplikasi pyraclostrobin memberikan dampak positif pada fisiologis tanaman yang menyebabkan peningkatan terhadap hasil tanaman dengan modifikasi keseimbangan hormon dan menunda penuaan tanaman. (Koehle et al., 2003) menambahkan bahwa pyraclostrobin mengubah stasus fitohormon yang terkandung pada jaringan tunas dan melakukan penghambatan hormone eetilen. Pyraclostrobin meningkatkan toleransi terhadap stres lingkungan, terutama meningkatkan toleransi terhadap kekeringan (musim kering). Hormon etilen ialah hormon yang merespon ketika tanaman mengalami stres, termasuk stres kekeringan akibat peningkatan suhu udara (Taiz dan Zeiger, 2004). Kanungo dan Juhie (2014) juga 
W.N. Lailiya, K.P. Wicaksono dan E. Widaryanto/ Buana Sains Vol 18 No 1 : 29-34

menambahkan bahwa dengan
pengaplikasian pyraclostrobin yang
diberikan pada tanaman dapat
meningkatkan laju fotosintesis dan
memperpanjang masa hidup daun
bendera dengan kandungan klorofil yang
tinggi.

\section{Analisis Stomata Daun Tanaman kopi}

Daun merupakan organ tanaman yang berfungsi sebagai tempat proses fotosintesis dan sebagai kontrol dalam mempercepat penyerapan air atau unsur hara dari dalam tanah sehingga jumlah daun dan luas daun akan sangat mempengaruhi proses fotosintesis. Jika jumlah daun banyak dan luas daun lebih besar maka kemampuan fotosintesis lebih tinggi dibandingkan dengan jumlah daun dan luas daun sedikit. Hal ini sesuai dengan pernyataan Djumali (2011) bahwa semakin luas ukuran daun semakin banyak energi yang terpanen sehingga proses fotosintesis semakin tinggi.

Pada pengamatan jumlah daun dan luas daun, hasil analisis ragam menunjukkan bahwa metode aplikasi pyraclostrobin dengan konsentrasi yang berbeda tidak memberikan pengaruh nyata jumlah daun dan luas daun yang terbentuk pada cabang bagian atas, tengah dan bawah pada tiap-tiap perlakuan. Hal ini terjadi karena tanaman kopi merupakan tanaman tahunan dan tanaman tersebut dalam kondisi yang seragam. Tetapi, terdapat perbedaan jumlah daun pada cabang bagian atas tengah dan bawah. Berkurangnya energi cahaya matahari yang dapat diserap oleh tanaman dapat mengakibatkan tanaman mengalami etiolasi (Gunadi et al., 2008). Lambers et al. (1998) menyatakan bahwa salah satu bentuk penyesuaian akibat dari berkurangnya cahaya yang dapat diserap oleh tanaman ialah dengan meningkatnya luas daun agar terpenuhi kebutuhan cahaya yang aktif dalam proses fotosintesis. Kanungo dan Juhie (2014) menambahkan bahwa pengaplikasian pyraclostrobin pada tanaman dapat meningkatkan laju fotosintesis dan memperpanjang masa hidup daun bendera (Gambar 1).

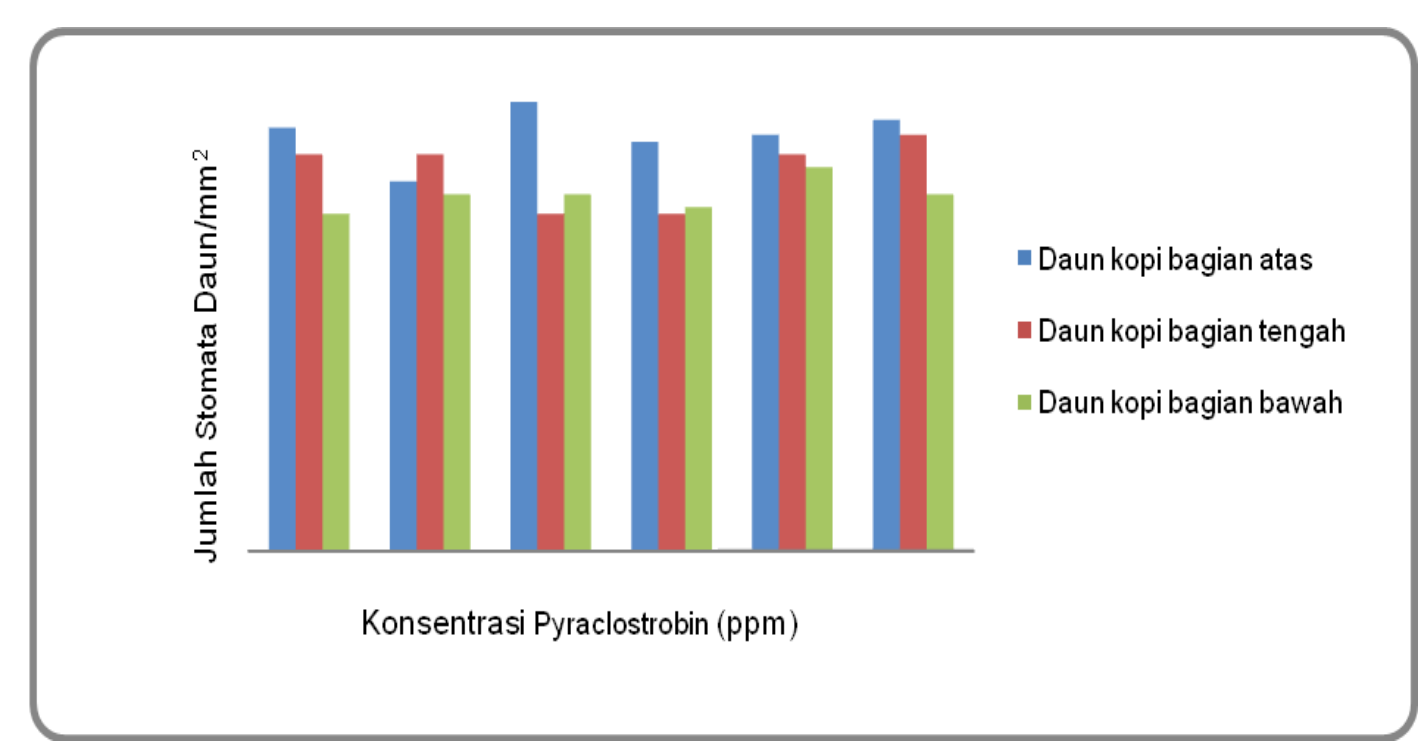

Gambar 1. Histogram kandungan klorofil daun tanaman kopi bagian pada berbagai konsentrasi pytraclostrobin 
W.N. Lailiya, K.P. Wicaksono dan E. Widaryanto/ Buana Sains Vol 18 No 1 : 29-34

Tabel 1. Rata-rata jumlah buah kopi per cabang bagian atas pada berbagai konsentrasi pyraclostrobin

\begin{tabular}{|c|c|c|c|c|c|c|}
\hline \multirow{2}{*}{ Pyraclostrobin (ppm) } & \multicolumn{6}{|c|}{ Cabang Atas } \\
\hline & \multicolumn{2}{|l|}{$4 \mathrm{MSA}$} & \multicolumn{2}{|c|}{$6 \mathrm{MSA}$} & \multicolumn{2}{|l|}{$8 \mathrm{MSA}$} \\
\hline $\mathrm{P} 0(0)$ & 74,84 & $\mathrm{a}$ & 74,01 & $\mathrm{a}$ & 61,19 & $\mathrm{a}$ \\
\hline P1 (150) & 97,97 & $\mathrm{ab}$ & 90,81 & $\mathrm{ab}$ & 84,47 & abc \\
\hline P2 (300) & 129,91 & $\mathrm{bc}$ & 124,02 & $\mathrm{ab}$ & 119,03 & c \\
\hline P3 (450) & 123,54 & $\mathrm{bc}$ & 118,53 & $a b$ & 114,10 & $\mathrm{bc}$ \\
\hline P4 (600) & 144,98 & $\mathrm{c}$ & 136,93 & $\mathrm{~b}$ & 127,45 & c \\
\hline P5 (750) & 134,09 & $\mathrm{bc}$ & 92,96 & $\mathrm{ab}$ & 74,00 & $a b$ \\
\hline BNT 5\% & 45,84 & & 54,75 & & 44,82 & \\
\hline KK \% & 25,88 & & 15,74 & & 17,30 & \\
\hline
\end{tabular}

Keterangan: Bila didampingi huruf yang sama pada umur dan kolom yang sama menunjukkan tidak beda nyata berdasarkan uji BNT 5\%; msa=minggu setelah aplikasi

Tabel 2. Rata-rata jumlah buah kopi per cabang bagian tengah pada berbagai konsentrasi pyraclostrobin

\begin{tabular}{lrrrlrl}
\hline \multirow{2}{*}{ Pyraclostrobin (ppm) } & \multicolumn{5}{c}{ Cabang Tengah } \\
\cline { 2 - 7 } & 4 MSA & 6 MSA & 8 MSA \\
\hline P0 (0) & 57,93 & $\mathrm{a}$ & 52,14 & $\mathrm{a}$ & 50,24 & $\mathrm{a}$ \\
P1 (150) & 111,56 & $\mathrm{ab}$ & 81,35 & $\mathrm{ab}$ & 79,14 & $\mathrm{ab}$ \\
P2 (300) & 115,36 & $\mathrm{~b}$ & 90,93 & $\mathrm{~b}$ & 84,54 & $\mathrm{ab}$ \\
P3 (450) & 122,32 & $\mathrm{~b}$ & 108,47 & $\mathrm{bc}$ & $108,32 \mathrm{bc}$ \\
P4 (600) & 156,63 & $\mathrm{~b}$ & 143,77 & $\mathrm{c}$ & 141,26 & $\mathrm{c}$ \\
P5 (750) & 104,66 & $\mathrm{ab}$ & 84,96 & $\mathrm{ab}$ & 78,34 & $\mathrm{ab}$ \\
\hline BNT 5\% & 56,85 & & 41,55 & 41,32 & \\
\hline KK \% & 33,87 & & 23,28 & 16,88 \\
\hline
\end{tabular}

Keterangan: Bila didampingi huruf yang sama pada umur dan kolom yang sama menunjukkan tidak beda nyata berdasarkan uji BNT 5\%; msa=minggu setelah aplikasi

Tabel 3. Rata-rata jumlah buah kopi per cabang bagian bawah pada berbagai konsentrasi pyraclostrobin

\begin{tabular}{|c|c|c|c|c|c|c|}
\hline \multirow{2}{*}{ Pyraclostrobin (ppm) } & \multicolumn{6}{|c|}{ Cabang Bawah } \\
\hline & $4 \mathrm{MSA}$ & & $6 \mathrm{MSA}$ & & $8 \mathrm{MSA}$ & \\
\hline P0 (0) & 55,36 & $\mathrm{a}$ & 42,84 & $\mathrm{a}$ & 42,22 & $\mathrm{a}$ \\
\hline P1 (150) & 69,98 & $a b$ & 40,58 & a & 39,79 & $\mathrm{a}$ \\
\hline P2 (300) & 76,87 & $a b$ & 62,00 & $\mathrm{ab}$ & 60,43 & $\mathrm{~cd}$ \\
\hline P3 (450) & 100,67 & $\mathrm{~b}$ & 76,82 & $\mathrm{bc}$ & 75,20 & $\mathrm{~d}$ \\
\hline P4 (600) & 100,90 & $\mathrm{~b}$ & 96,08 & $\mathrm{c}$ & 92,87 & e \\
\hline P5 (750) & 69,22 & $\mathrm{ab}$ & 55,39 & $\mathrm{ab}$ & 56,68 & $\mathrm{bc}$ \\
\hline BNT 5\% & 35,82 & & 23,25 & & 16,85 & \\
\hline $\mathrm{KK} \%$ & 22,79 & & 18,98 & & 16,92 & \\
\hline
\end{tabular}

Keterangan: Bila didampingi huruf yang sama pada umur dan kolom yang sama menunjukkan tidak beda nyata berdasarkan uji BNT 5\%; msa=minggu setelah aplikasi 
W.N. Lailiya, K.P. Wicaksono dan E. Widaryanto/ Buana Sains Vol 18 No 1 : 29-34

\section{Jumlah Buah Tanaman Kopi}

Hasil analisis ragam menunjukkan bahwa pada metode penyemprotan pyraclostrobin memberikan pengaruh yang nyata pada jumlah buah kopi pada cabang atas, tengah dan bawah. Pengamatan 4 msa pada cabang bagian atas menunjukan bahwa perlakuan P4 (600) jumlah buah meningkat sebesar 48,37\% dibandingkan dengan perlakuan P0 (tanpa Penyemprotan). Sedangkan pada umur pengamatan 6 msa cabang bagian atas menunjukkan bahwa perlakuan P4 (600) jumlah buah meningkat sebesar $45,73 \%$ dibandingkan dengan perlakuan P0 (tanpa penyemprotan). Selanjutnya pada cabang bagian atas umur pengamatan $8 \mathrm{msa}$ menunjukkan bahwa P4 (600) jumlah buah meningkat sebesar 51,98\% dibandingkan dengan P0 (tanpa penyemprotan) seperti yang ditunjukkan pada tabel 1.

Pada cabang bagian tengah umur pengamatan 4 msa menunjukan bahwa perlakuan P4 (600) jumlah buah meningkat sebesar 44,64\% dibandingkan dengan perlakuan P0 (tanpa penyemprotan). Sedangkan pada umur pengamatan 6 msa cabang bagian tengah menunjukkan bahwa perlakuan P4 (600) jumlah buah meningkat sebesar 63,73\% dibandingkan dengan perlakuan P0 (tanpa penyemprotan). Selanjutnya pada cabang bagian tengah umur pengamatan 8 msa P4 (600) jumlah buah meningkat sebesar 64,43\% dibandingkan dengan P0 (tanpa penyemprotan) seperti yang ditunjukkan pada table 2 .

Pada pengamatan jumlah buah menunjukkan bahwa jumlah buah dan bobot buah tertinggi terdapat P4 (600). Hal ini sesuai dengan pernyataan Anand et al., (2013) yang menyatakan bahwa keguguran buah terjadi karena faktor fisiologis yang terjadi melalui pengaruh iklim terutama kelembaban dan kekeringan yang berpengaruhpada kerontokan buah.Koehle et al., (2003) menambahkan bahwa pyraclostrobin selain beraktivitas pada mitokondria pada tanaman juga berperan mereduksi respirasi dalam tanaman tersebut. Penurunan respirasi membuat tanaman mampu untuk menyimpan lebih banyak senyawa karbon untuk pertumbuhan dan memacu reaksi rantai dari perubahan fisiologis dalam tanaman. Pengaruh positif dari perubahan fisiologis dapat meningkatkan aktivitas nitrat reduktase yang merupakan enzim yang digunakan untuk pembentukan nitrogen pada tanaman. Beberapa manfaat lain dari peningkatan aktivitas nitrat reduktase pada tanaman antara lain meningkatkan aktivitas enzim superoksida dismutase dan peroksidase yang menghilangkan panas. Enzim ini dapat mengurangi stres oksidasi untuk merespon lingkungan yang kacau seperti kerusakan ozon dan stres panas. Koehle et al., (2003), pyraclostrobin mampu meningkatkan toleransi terhadap panas. Stres panas dihubungkan dengan peningkatan aktivitas enzim superoksida dismutase (SOD). Nitrat oksida juga dihubungkan dengan peningkatan toleransi terhadap panas (Larson, 1997).

Pyraclostrobin akan membantu pupuk tambahan pada saat aplikasi. Mengidentifikasi sumber pupuk yang sinergis meningkatkan hasil dengan pengaplikasian pada tanaman akan membantu mengurangi penyakit tanaman, dapat mengurangi biaya dan memberi pupuk tambahan ketika permintaan tanaman dalam kondisi maksimum (Kuswanto dan Wicaksono, 2011). Pyraclostrobin juga berperan untuk meningkatkan toleransi terhadap cekaman suhu, kelembaban dan kekeringan. Hormon yang merespon ketika tanaman mengalami cekaman atau stres ialah hormon etilen. Hormon etilen 
W.N. Lailiya, K.P. Wicaksono dan E. Widaryanto/ Buana Sains Vol 18 No 1 : 29-34

dapat menyebabkan tanaman lebih cepat masak daripada fase pematangan secara nirmal dan menyebabkan keguguran bunga dan biji saat merespon stres. Hormon etilen ini muncul ketika tanaman mengalami proses kematangan, mengalami luka ketika pengguguran daun dan sebelum patogen memicu kematian sel. Dengan pengaplikasian pyraclostrobin pada tanaman dapat menghambat enzim-enzin yang terlibat langsung dalam produksi hormon etilen sehingga memperlambat pemasakan buah. (Taiz dan Zeiger, 2004).

\section{Kesimpulan}

Pemberian pyraclostrobin mampu meningkatkan jumlah buah dan hasil panen. Pemberian pyraclostrobin dengan konsentrasi $600 \mathrm{ppm}$ mampu meningkatkan bobot biji sebesar 81,15\% serta menurunkan terjadinya keguguran buah hingga mencapai 55,75\% dibandingkan dengan perlakuan tanpa pemberian pyraclostrobin.

\section{Daftar Pustaka}

Ammermann, E., G. Lorenz, G. Schelberger, K. Mueller, B. Kirstgen, R. Kirstgen, and H. Sauter, 2000. Pests and Diseases.in: BCPC Conf. p.541-548

Anand, C., G., Awati, M. G. D'souza, G. F. Kumar, P., Koler, P. Nagarattnamma. 2013. Physiological Constraints in Coffee Production During Monsoon and Remedial Measures for Achieving Maximum Crop Yield. Indian Coffee (4) : 4-10

Giuliani, M. M., E. Nardella., G. Gatta., M. Quintadamo and A. De Caro. 2011. Processing Tomato
Cultivated Under Water Deficit Conditions : the effect of Azoxistrobin. J. of Horticultural Science. 914: 287-294

Kanungo, M and J. Juhie. 2014. Impact of Pyraclostrobin (F-500) on Crop Plants. J of Plant Sci. 1(3):174-178

Koehl, H., K. Grossmann, T. Jabs, M. Gerhard, W. Kaiser, Glaab and S. Herms. 2003.Physiologiical Effects of the Strobilurin.Fungicide F 500 on Plants. Fungicides and Antifungal Compounds III, bonn, Germany. p. 61-74

Kuswanto, K.P. Wicaksono., Sudakir and B. Edson. 2013. Improving Nitrogen Fertilizer Absorption and its Effect on Quality and Seed Yield of Corn (Zea maysL.).Agrivita. J. 35 (2):201-206

Lambers, H., T.L. Pons and F.S. Chapin. 1998. Plant Physiological Ecology. 2nd ed. springer sci. New York. USA. p. $73-75$

Racsko, J., Leite, G. B., Petri, J. L., Zhongfu, S., Wang, Y., Szabo, Z., (2007). The Role of Inner Agents and Environmental Factors in the Drop of Flowers and Fruits. International. J. of Horticultural Science. 13(3):13-23

Taiz, L. and Zeiger, E. 2004. Fisiologia Vegetal [Plant physiology], 3.ed. Porto Alegre: Artmed Editora. p. 720

Vaast, P., Angrand, J., Franck, N., Dauzat, J., and Ge'nard, M. 2005. Fruit Load and Branch Ringbarking Affect Carbon Allocation and Photosynthesis of Leaf and Fruit of Coffea Arabica in the Field. Tree Physiology. 25(6):753760 